\title{
"Making Families" \\ Child mobility and familiar organization in Cape Verde
}

\section{Andréa Lobo}

University of Brasilia

\section{Resumo}

$\mathrm{O}$ artigo pretende demonstrar que o universo do parentesco na sociedade crioula de Cabo Verde não é um dado pré-definido, as relações de parentesco não são irrevogáveis e sem necessidade de reiteração. As relações familiares são analisadas como construção, um projeto que é fruto de negociação constante entre os membros. $\mathrm{O}$ argumento central é o de que, em Cabo Verde, as relações familiares se caracterizam por um comprometimento mútuo, contatos sociais regulares e um fluxo intra e inter-doméstico de benefícios materiais e não-materiais. Tais requisitos são fundamentais para a construção do sentimento de proximidade e atuam para fortalecer laços préexistentes, de parentesco.

Palavras-chave: Cabo Verde, organização familiar, parentesco, relatedness.

\begin{abstract}
This article is aimed at demonstrating that the universe of kinship in the Creole society of Cape Verde is not pre-defined, kinship relations are not irrevocable and free from the need for reiteration. Family relations are analyzed as a construction, a project which results from constant negotiations among its members. The central argument is that, in Cape Verde, family relations are characterized by mutual commitment, regular social contacts and an intra and inter-domestic flow of material and immaterial benefits. These requisites are fundamental for construction of the feeling of proximity and strengthen pre-existing kinship bonds.
\end{abstract}

Keywords: Cape Verde, Family organization, kinship, relatedness 


\title{
"Making Families" \\ Child mobility and familiar organization in Cape Verde
}

\author{
Andréa Lobo \\ University of Brasilia
}

\section{Introduction}

In 2004, during one of the many late afternoons I used to spend with my friend Bia in her backyard in a Cape Verdean city, she was particularly anxious due to a recent critical event in her family. In addition to her husband and two grown children who lived in her house, she raised two young ladies, 10 and 11 years of age, and her young grandson, her son's son. The little boy brought joy to the afternoons during which we made donetes, ${ }^{1}$ always asking Bia for some dough, to which she would reluctantly give in and smear some on the tips of his fingers. That afternoon the house was empty and Bia, very melancholic, told me the mother had taken the little one away, from that moment forth he would live with her at her parents' house. Bia saw that as an act of revenge on the part of the mother, because Bia's son had found a new pequena. ${ }^{2}$ She was worried that the child "would only be well taken care of and fed under her care."

That afternoon she told me she had already aguentado $0^{3}$ many children, including the two girls who lived with her and were treated as family. Likewise, there were those who helped (ajudaram) with her own children. Both of them lived with their mother at an early age and, throughout their lives, with other ladies who helped to raise them, both in Boa Vista and in Praia, where they attended high school. While we talked, Bia cooked a broth for dinner and, as usual, prepared some vessels to send some broth to those she treated with grandeza. ${ }^{4}$ The kids delivered these vessels.

\footnotetext{
1 Sweet doughnouts covered in a sugar coating.

2 Word used to refer to a grilfriend.

3 Words in italic refer to local terminology and are explained and/or analyzed throughout the article.

4 By observing the daily life of a household, it is possible to see a continuous flow of goods, services and information in reciprocal circulation among houses. Good relatives exchange meals, ajudam with
} 
The situation Bia faced, as well as her family history, are not uncommon. Therefore, I use it as the central point in my argument in this article. However, the protagonists in these pages are not women, mothers or grandmothers who are so important to the daily lives of families in this society, in this article I gaze upon children, understood here as the main stakeholders in the intersubjective relations which make up kinship in Cape Verde.

Based on ethnographic data, I develop the argument that the universe of kinship in this society is not pre-defined by consanguinity, i.e., kinship relations are not irrevocable and they do require reiteration, as Meyer Fortes (1969) said. Contrary to the author's conceptions, who stated that the moral character of kinship and its bonds, albeit temporal, is "unconditional and out of discussion;" family relations are analyzed here as a construction, a project which is the result of constant negotiations among its members.

In Cape Verde, family relations are characterized by mutual commitment, regular social contacts and intra and inter-domestic flow of material and non-material benefits. These requisites are fundamental for construction of a feeling of proximity and strengthen pre-existing kinship bonds. ${ }^{5}$ Consanguinity bonds are not, therefore, irrevocable and need daily care in the form of small acts of sharing objects, food and attention.

Children are fundamental players in these family contexts. Their lives are characterized by intense mobility which places them in the condition of both subject and object of sharing and reciprocity. This child mobility strengthens and/or creates bonds among groups, produces relations of co-inhabitance and domestic cooperation among people who are laterally co-related, in addition to constructing maternities and paternities. I therefore consider it correct to state that child mobility generates alliance relations which make families in this context. ${ }^{6}$

The terms suggested by Mauss (2003) when stating the principle of

one anothers'children and lend kids to assist in mandados. Thus, to treat someone with grandeza means to please, always remember, give attention to. In order to show these feelings, essentially, food is made and shared on a daily basis. People in grandeza may be relatives or neighbors and friends treated as kin; whateve the case these people are those considered the closest, who can be counted on.

5 The expression "making family" is analyzed here in the context of strengthening and maintaining bonds of affinity and consaguinity, however, it should be noted that this expression also applies for construction of kinship relations in cases where it does not exist in its biological aspects, i.e., expandingfamily relations among neighbors, friends and persons of grandeza.

6 I thank João de Pina Cabral for suggesting this approach to child mobility in Cape Verde. 
connection between people and objects in exchanges, i.e. based on the principle of gifting, the movement of giving, receiving and returning, are considered here. The exchange mechanism within what is considered as the family domain, brings out the manner in which people in Cape Verde relate with those who are considered closest by means of goods (tangible or intangible) which are exchanged on a daily basis. Therefore, like Mauss when dealing with gifting, I propose to think of these exchange relations as alliance relations, in a broader sense.

More specifically, inspired by an interesting discussion proposed by Pina Cabral (2010) upon analyzing homonyms as institutions, my focus falls on analysis of child mobility as a locus for alliance relations, since interactions refreshed by child flows overlap filiation relations in the history of the person by a process of triangulation (2010:325). As proposed by the author, the word triangulation is taken in its geometric sense and is connected with cases in which related beings exist by the mutual relationship with a third being which constitutes a necessary point of triangulation. ${ }^{7}$ This third element, in my case, is the grandmother.

These triangulation relations as seems to be the case in Cape Verde, take place early on in the lives of individuals, leading both to consolidation of their condition as persons in this world and formation of their relatedness $(2010: 325)^{8}$ universe. It is by means of circulation that these triangulations become effective in the lives of little ones, making filiation bonds more complex and strengthening and/or creating conditions for conjugal alliances. Analysis of the complex relation between children and maternal and paternal grandmothers including child mobility serve as the stage for my argument that the alliance can be perceived beyond an Eurocentric conception close to the idea of "marriage" (Pina Cabral, 2010).

By adopting a broader view of kinship as relatedness and taking ethnographic data seriously, the alliance may emerge as a type of relation which draws bonds among people by means of their connections with others, i.e., consolidates social beings by instituting triangulation relations (Pina Cabral, 2010). Seeing child mobility as an alliance institution makes it possible to

7 Pina Cabral remits to the Lévi-Strauss' argument (1976) which analyzes the role of the mother's brother in the alliance as a type of triangulation.

8 I use the word relatedness based on Carsten (2000). 
grasp circulation of children in its most significant aspect: that of social space for sharing which amplifies and strengthens lateral and vertical kinship bonds, since it creates maternities, paternities and conjugalities.

The word relatedness was minted by Carsten (2000) in an attempt to step out of the discussion about the opposition between biological and social which was present in most anthropological kinship studies. The author suggests a change in vocabulary and proposes to use the idea of relatedness as an alternative to kinship and in order to "mark an opening to indigenous connection languages" (2000:4). This approach made it possible to pay the necessary attention to local relatedness forms which go beyond ties of blood, semen and breast milk - revealing shared substances which create the type of profound and long-lasting relations normally associated with relatives.

I use the idea of relatedness to account for the daily universe of these families because I believe the case presented here makes the idea, as proposed by Carsten, more complex. Triangulation processes between mothers/fathers, children/grandchildren and grandmothers, which are the object of this study, present us with a family life constructed in a permeable space, crossed by practices and relations which extend to different domestic units which are interconnected by children, objects and values in circulation. It is in this permeable space that the universe of relations an individual has with the necessary elements to locate him or herself in the world takes place. However, this constructed universe does is not free of blood ties - it strengthens them and expands them by means of alliances.

\section{The ethnographic context}

Throughout 2004 and 2005 I carried out field work in one of the 10 islands which make up the Cape Verdean archipelago, the Island of Boa Vista. The research was developed in the population of Sal-Rei Village and the objective was to work with women's migratory flows and their influences on transformations which have taken place in local family organization (Lobo, 2006). Sal-Rei was the main village in the island and housed approximately 2500 inhabitants, of the 4209 residents spread out in the seven small villages making up the arid landscape characteristic of that archipelago. ${ }^{9}$ The main economic

9 For more information on the meaning of aridity in Cape Verdean identity, see Lobo (2001) 
activity was subsistence farming, although it did not circulate financial resources, these came mainly from emigrated women who lived in Italy ${ }^{10}$ and worked as housekeepers. ${ }^{11}$

Cape Verde is an archipelago located in the Atlantic Ocean and settled by the Portuguese in 1460. Its effective occupation took place late, in the context of slave trade from the African continent to Europe and the Americas. Its social formation process is, therefore, a result of a clash between Portuguese and Africans, originating a Creole society marked by heterogeneity. The country is historically characterized as a diaspora society, given its historical specialization of exporting people to all corners of the planet by means of emigration. It is in this context that a type of family organization becomes structured, with an apparent ambiguity - essentially patriarchal, albeit holding deep characteristics of matricentrality (Couto, 2001; Dias, 2000; Monteiro, 1997).

Briefly speaking, this Family organization has the following general characteristics: mobility of men, women and especially children among many domestic units ${ }^{12}$ as part of family dynamics; constant sharing among houses, the central units strongly associated with women and children; men characteristically have relations marked by absence and distance form the daily lives of their children and their children's mothers, contributing financially and socially in a sporadic manner; many grown women emigrate, ${ }^{13}$ leaving behind family members, children and the fathers of their children on the island.

Domestic units are heavily centered on the figure of the grandmothermother. Although operating in a patriarchal ideal, in which men have authority over the destiny of their children and the course of a woman's life,

10 In the case of Boa Vista, most women go to Italy, although there is also a considerable number of them in France and Portugal. For more information about the destinies of out migration in Boa Vista Island, see Lobo (2006).

11 In more recent studies, I have observed significant changes in the socioeconomic context of the island due to the growing inflow of tourists from European centers such as Italy, France, Germany and Portugal. In the past years, Boa Vista was granted construction of an international airport, resorts and luxury hotels. Consequently, the last Census (2010) indicates a steep increase in population due to intense internal migration (inter-island) and immigration of Africans from the continent.

12 House is used here according to the native understanding, in which each one takes on the meaning of family as primary social unit. This understanding of house seems to be close to that of Carsten \& Hugh-Jones (1995), who, in dialog with Lévi-Strauss, move away from the idea of house as a moral person. According to the authors, the house is the universe of the most fundamental realtions in peoples' lives, a social space in which relations are constructed from commensality and co-substantiality.

13 The flow of emigration is more intense among young women between the ages of 18 and 30. 
in practice women have an important social and economic role, since predominant affectionate arrangements encourage circulation of men in several domestic units throughout their adult lives. What I mean is that affectionate relations between men and women, even involving children, have characteristic non-fixation of the couple in conjugal union at a first moment: they live together and share tasks involving care for children and expenses.

Furthermore, men often have simultaneous affectionate relations with more than one woman, and these relations may generate children. Lastly, it should be noted that the meanings of masculinity include the relative distance from the domestic universe, especially concerning child rearing. All of this cooperates in placing centrality on women within families, a position which is reinforced by networks of women operating out of houses and among generations, by means of sharing and circulation of goods, values and persons.

It is known that these characteristics should be analyzed over time, i.e., they tend to become stronger or weaker depending on the stage of development in the domestic cycle. Over the years, men have a tendency of becoming fixated with one of their mother-of-children, usually the first. The official marriage, which generally takes place when the couple's children are grown up, marks this stage of male "serenity" regarding domestic matters.

Affective matrimonial relations are therefore formed by a sequence of actions involving women living in their parents' houses and commuting on a daily basis to the companion's parents' house, where they sleep together. During the day, these women return to their houses, where they participate in cooking food which is often sent in containers to the companion's domestic unit by means of children - preferably the couple's children. The offspring of this relation normally stay at the maternal house, although they circulate between both, which has direct effects on their formation as people and creation of their universe of relatedness.

Sharing is, therefore, a fundamental category to understanding family relations in Cape Verde. By analyzing sharing, mutual assistance and solidarity practices among people and domestic groups, the fundamental concept of "making family" can be grasped, i.e. strengthening bonds between relatives and creating kinship where it did not previously exist. According to local concepts, the family results from production based on experiences involving living together and domestic cooperation between people, i.e., the family universe is seen as a process which is constructed on a daily basis. 
Meanwhile, just as kinship relations must be obtained, negotiated and nurtured, the lives of individuals and their positions in the family context result from choices and negotiations, not to be understood as inevitable duties which are pre-established in the system. Understanding that this universe is a framework composed of multiple possibilities in which the trajectories of individuals are many and that their positions are conquered based on their paths in life is central to understanding families as a process in Cape Verde.

\section{Children and possible circulations}

In this context children are fundamental links in maintenance of solidarity networks. They are everywhere, an attentive eye over local daily life is enough to show them participating in many events and chores which make up the island's routine. ${ }^{14}$ They are the most frequent mediators between houses. They carry messages, presents and exchange items. It is children who women send with objects and food which are so essential for the reciprocity that keeps houses connected. It is difficult to imagine a house without the children who live there or come to spend the day.

Chores for children between the ages of 5 and 10 include going to stores to buy food supplies, selling foods made by women door-to-door (donates, fish dumplings, bread, cakes etc.), transporting objects and, especially, food among houses. Food preparation and flow, be it by selling or distributing to people of grandeza, are central errands in the routines of women and small children. I return to the ethnographic case which introduced this article and remember distribution of the broth made for dinner being separated and distributed to other houses. The quintal ${ }^{15}$ (backyard) in these houses is where mandados are carried out. Furthermore, it is where people, objects and information are exchanged and shared.

\footnotetext{
14 In spite of widespread insertion in community life, there are two moments in sociability which they are barred from, situations of illness and death. Houses of grievously ill or dead people are the only places in Boa Vista where children cannot be found. These visits are obligatory and formal. There is little conversation, plenty of drinks and food in a silent environment. Children are not welcome at these events.

15 Backyards are adjacent to kitchens. There is generally a wood stove and a counter with basins to wash household utensils. It is here that women and children spend days dedicated to food preparation and other chores. The backyard gate is used by people coming and going constantly. Kitchens, although equipped with sundry appliances, are only used during feasts. Backyards serve as mediation spaces between public streets and private homes, thus being a hybrid space.
} 
When children are older, boys and girls become more distinct, with girls being increasingly responsible for taking care of smaller children. The words aguentar or pegar are used by the young girls to refer to this act of childcare - feeding, bathing, comforting, putting them to sleep and taking them from house to house are involved. These chores are always performed under the scrutiny of older women, generally grandmothers. Young ladies seem to appreciate these chores. Many a time did I witness conversations which showed competition between young girls to pegar someone's children. During interviews or conversations, the topic of children they had aguentado often came up as a source of pride.

In addition to taking and bringing money, food and goods, children also bring and take words between houses, transporting messages and rumors. Once more, the backyard shows up as a privileged space for circulation, it is on backyards that the latest news from the village and rumors which set local life in motion are transmitted. Lastly, it is interesting to point out that in situations of conflict between families, children are the only ones allowed to circulate between the houses when adults no longer do it. Therefore, children, due to their mobility character, personify and reproduce a large part of exchange relations which are necessary for maintenance of a broad concept of family.

This concept is heavily connected with food production and sharing. It is not only about who feeds the children, as in many studies about nutrition as a privileged means of producing kinship (Carsten, 1991; Viegas, 2003; Modell, 1998), but also about participation of little ones in production and distribution of food to be consumed in and out of houses. What I wish to emphasize is that, in addition to the importance of daily acts of feeding and taking care of a child, construction of belonging in a domestic space at the stage of formation as a person is connected with participation in food production and distribution. After all, sharing among houses is a practice which expands and strengthens kinship bonds, depending on the presence of children in domestic spaces.

Children are therefore not only important means for sharing and reciprocal exchanges, but also objects of sharing and reciprocity. In addition to daily circulation, being in many houses at once has another meaning. Mobility is 
extended to what we call circulation ${ }^{16}$ of children. What this means here is that others, who may be relatives or not, may aguentar a child for some time. This happens frequently among people who consider themselves to be relatives. Aguentar is a Creole word with two meanings worthy of more careful clarification, as it can be understood as "to take care of" (as in the case described above, in which young ladies aguentam or pegam smaller children), or as "raising" a child, a function which implies taking responsibility for nutrition, shelter, comfort and support. This category therefore indicates the dual character of this circulation, with short or long duration. It is this type of mobility I would like to look at more closely.

Few of the youths and adults I interacted with during my field studies had resided in only one house during their lives. A child would commonly live somewhat permanently in the house of a relative close to the mother, especially the maternal grandmother. However, they move around from house to house, both for brief sojourns and longer periods. Arrangements and reasons for circulating children are many, explanations range from the child's will to the need for a child's company to assist in mandados, to financial reasons, proximity to school, mother's emigration etc. This variation extends to the length of stay, which can be months, years or life.

There has been myriad intellectual production about circulation, fostering and child adoption. Despite different approaches, these categories reflect practices in which children, for different reasons, are raised by adults who are not their biological parents (permanently or temporarily), often treated and accepted as family members in the foster homes. As Schneider (1984) pointed out, the Euro-American understanding of kinship as a biological connection influenced approaches used by Anthropologists, with this biocentrism resulting in categories such as "fictitious kinship". Ethnographic approaches on adoption, child circulation or fostering challenge this view and lead us back to our focus in our analyses regarding the quality of relationess and the meanings of kinning processes (Howell, 2009).

Howell, in his thematic review of transnational adoption, revisits the approaches used and draws attention to field experiences in Oceania, where adoption and fostering are widespread. The discussion created by these

16 I use circulation of children here meaning foster children. Adoption is not the appropriate category in my case, considering that circulation of children is not formal or permanent in nature. Claudia Fonseca (2006) also uses the word circulation in her case study in the outskirts of Porto Alegre. 
studies places kinship as something partly made up of shared biogenetic substances and partly exchanges of other substances. These relations of nutrition and sharing of substances have the potential to overcome, over time, natural kinship relations (2009).

Western African literature about fostering emphasizes that children circulate with the objective of weaving geographically dispersed branches of the family. For example, Esther Goody, in a study about the Gonjas (1982), when discussing child circulation, differentiates crisis from voluntary circulation. In the latter case, the objective is cementing kinship bonds, seeing the child as a family asset. What these studies point out is that fostering is more than micro-movement of children, is also a form of replication and reproduction of society. ${ }^{17}$

Although it is not aligned with the author's argument about sharing children between social and biological parents as a practice with the function of being rational in these societies, the hypothesis raised in African fostering studies leads us to a reflection about some aspects of the Cape Verdean case. Even amidst tension and conflicts, the ease children have in circulating among houses seems to make up for many tendencies which could otherwise weaken solidarity in the family as a whole.

Therefore, in addition to circulating objects and information and keeping domestic units in touch, the practice of living in more than one house creates multiple belongings which strengthen filiation or alliance bonds between related groups. Children are thus central in a context in which relations between different generations and relatives are marked by tension and, to a large extent, delicate bonds under constant risk of breaking. Allow me to better explore this point based on analysis of some characteristic relations in the local domestic universe.

\section{Maternities}

Kinship studies in African contexts which discuss the generational topic are not new in Anthropology. In his first foundational contributions, RadcliffeBrown (1952) suggested there is equivalence in alternated generations and

17 Goody's analysis (1982) is connected to British structural-functionalism. Its objective would therefore be to justify fostering as functional and reasonable, not covering ontological, moral and semantic premises for this practice. 
opposition in close generations. According to the author, amiable equality between grandparents and grandchildren serves to minimize tensions which result from the relations between parents and children, which are, in turn, marked by parental authority and severe obligations. Reinforcing this, Fortes (1969) describes the Tallensi pointing to conflicts between parents and children and friendly relations between alternated generations. Tallensi grandparents spoil their grandchildren, are caring and sympathetic, leaving discipline and resource allocation up to the parents.

In turn, recent studies in Africa seek to reflect on the generational topic in dialog with our science's "ancestors". The volume about Africa under the title "Grandparents and Grandchildren", organized by Susan Whyte, Wenzel Geissler and Erdmute Alber, in 2004, is a reflection of the importance the topic has in contemporary production. In the introduction, the organizers draw attention to the fact that, while many authors continue to reproduce the classic image of the relation between grandparents and grandchildren as sympathetic and friendly, ethnographic situations reveal more complex realities. This is due to the fact that new ethnographies focus on everyday practices and the concreteness of substances shared by relatives (2004:4). These studies focus less on the institutional structure of kinship systems and more on relations constructed in daily practice. Therefore, in addition to perception of construction of daily life, they point out the importance of understanding grandparents and grandchildren in a temporal context, regarding changing standards in the societies under analysis.

In Cape Verde, the reasons for living with a grandmother are many, from situations in which everyone is living together in a single house, either due to financial difficulties or the mother's emigration, or even the desire of children or grandmothers. Living with a grandmother is a valid option, not restricted to special moments or emergencies. Mobility seems to be the key point here, the child may be with the mother or maternal grandmother, as well as he or she may spend time with the paternal grandmother or in the house of a different family member. One way or another, "to live with" is not necessarily considered a permanent arrangement in the life of a person, and this is valid for children. What makes grandmothers special is the fact that they are identified - complementarily to the mother - as the central member in the concepts $f$ house and family, both important categories for the feeling of social belonging. But what makes grandchildren special? 
Sharing food, room and board, as well as domestic production with grandchildren turn a woman into a grandmother. If she cooks for her grandchildren, feeds them and comforts them, it is up to them to help with household chores, show respect, give emotional support and guarantee reproduction of the house. Having a child of a child certainly constitutes a central characteristic in the organization of a house, as a common means of strengthening relations and social bonds, in addition to putting maternity into practice in this society. Grandchildren are integrated in daily tasks, boys and girls help in activities which are typically reserved for women, such as cooking, washing and transporting water, firewood or food. In summary, they are important to get many mandados done which grandmothers are usually no longer physically fit enough to get done, or are no longer among their priorities. Grandchildren also keep their grandmothers company, are caring and are seen as a source of joy in a house.

Grandmothers enjoy the presence of grandchildren, take pleasure in their company during a stage of the domestic cycle in which sons and daughters are already dedicated to construction of adult life in a society which finds in women's emigration the best alternative for reproduction. However, in addition to emotional comfort, being with grandchildren guarantees maintenance of rights in the mediation between parents and children. Not having grandchildren at home means abandonment and loss in many ways. Grandchildren are the insurance that children will continue to contribute financially, which is a substantial contribution to economic security at advanced ages. In the field, I observed that $84 \%$ of grandmothers aguentavam one or more grandchildren and that $37 \%$ of them received financial support from the mother or father of the child, in addition to a constant flow of goods and food to supply the central domestic unit inhabited by the grandmother. ${ }^{18}$

Thus, in order for these women to have a "good" life trajectory, they must be surrounded by grandchildren and, consequently, by children. Children are like the connections between relations, they bring the parts together to create the sum. Development of the domestic cycle, as understood by Fortes (1974), ends with the dispersion stage, during which grown children tend to form new units and the old parents tend to be left by themselves. Here, the

18 I worked with 43 families in the field, 20 of which I held intense daily contact with and developed friendships. 
ideal structure has daughters remaining for a long time and, even after their departure, grandchildren are incorporated into the unit. In a way, grandchildren represent continuation of the relation with daughters. Therefore, during a stage in the domestic cycle characterized by dispersion and emptying of the central domestic unit, grandchildren renew relations, strengthening social bonds between mothers and daughters and reinforcing the central role of the grandmother-mother in the domestic universe.

During my fieldwork, I observed that bonds between children and grandmothers who live in the same house are more affectionate than the bonds with the biological mothers. Daily acts of sharing and naming express the affectionate character of this relation. Both are central in the lifecycle of a person and make up what I call proximity. In this context, if kinship in Cape Verde has a strong character of relations constructed in daily actions by living together, can we claim that the grandmother has a more important role than the mother in the life of a child?

I cannot see here a differentiation which divides relationships into: grandmother/grandchild = proximity and affection and mother/child $=$ distance and authority. Both relations are characterized by affection and authority. Children are treated with care and attention, but limits are always set. In this regard, mothers and grandmothers are different. What changes is the form with which they live this experience, the manner they care for the children or grandchildren and how they experience this. The meanings of aguentar a child vary over time, being experienced distinctly by mothers and grandmothers.

It therefore does not seem correct to claim that there is competition between mother and grandmother, the latter at an advantage toward the former. What I observe is complementariness of functions and forms of treatment resulting from the current situation in the lives of these women. This union creates the local meaning of what a child needs to be happy and supported: differentiated attention from both the mother and the mamã. In turn, to exercise maternity at both stages of life means full exercise of maternity for a woman. To be a mother is, therefore, a cycle which begins with the birth of a child and is only closed when she ahs the chance of becoming a mamã.

Nonetheless, complementariness is not without tensions. Grandmothers' opinion of a child's well-being consists largely of constructions regarding the incapacity of young mothers to care for their children. The importance 
of grandmothers is produced based on this alleged deficiency on the part of the mothers, expressed in statements such as do not have time, have their heads full, lack of caring attention. These images create room for action in which grandmothers are appreciated for ajudar to carry out those functions seen as necessary for children, but which mothers are incapable of performing. If, on the one hand, this configuration generates complementariness between these women, it is a source of conflict on the other, especially when the expectations of mothers and grandmothers are not met.

Being aware of the several arrangements in this complementariness allowed me to observe these tensions. There is a set of potential conflicts in daily life which originate from the division of tasks between mothers, daughters and children. In order to construct the position of centrality, grandmothers dole out and monitor tasks for young mothers and children who they aguentam, as well as their behavior. They control in order to have role played as according to expectations, which is an exercise in authority which is frequently questioned and threatened by the younger generations. In the case of ladies, tensions arise from undesired affectionate unions, unexpected pregnancies, difficulties with financial contributions and, of course, incapacity to perform the role of mother. In the case of children, the threat comes from mobility and circulation.

As in the case which opened this article, Bia's case, the possibility that a child will live in a different house or simply leave on a mandado to return hours or days later is a reality which starts daily conflicts between members of a domestic group and, depending on the situation, tensions go beyond these boundaries, provoking fights between houses. That is the case of disputes over children between maternal and paternal grandmothers, in which the former wishes the child will live with her and makes use of rumors of lack of care and attention to denigrate the image of opposing women. Except for cases which are considered grave, in which disputes go to court, the child is the one who decides where to reside. ${ }^{19}$

Another factor which generates tensions in the local standards of grandchildren living with grandmothers is the image of a nuclear family widely

19 In an interesting study about a Tupi indigenous group in Bahia, Viegas analyzes attraction and "seduction" processes women use to lure children to their houses. The author uses the term "focal mother" to refer to mothers who are not the biological ones but take on the responsibility for keepong the little ones fed. 
disseminated by media and accounts of emigrated women working as housemaids in Italy. ${ }^{20}$ According to this ideal, younger women make known their wish to have what they call a normal family, i.e., in which the conjugal couple shares a home and parents raise their children. In the attempt to copy this model, young women press to have a new household started with their fathers-of-child, in which they can live and raise their children. In the cases in which the young couple move to a different location, the influence of grandmothers on their daughters and their offspring tends to weaken, since the presence of children in the routine of their grandmothers' houses becomes more sporadic. Older people are concerned about this tendency and blame modern times for these changes, in opposition to a past in which elders were more respected and appreciated.

In the case of relations between grandmothers and grandchildren, the quality of affection and the importance of grandmothers in mediation of vertical filiation relations are fundamental factors for its reproduction and reproduction of the system as a whole. However, family relations are contextoriented and contingent, relative to positions and strategies under constant reconstruction. Different perspectives regarding grandmothers and grandchildren show that roles are not fixed, but rather fluid and flexible, allowing room for negotiations which alter relations. Personal and social identities are developed and sustained in exchanges with others. Thus, how people see themselves is influenced by how others see them and how they behave toward them. This is not given, but constructed and reconstructed daily.

Exploring the universe of relations between children/grandchildren, mothers and grandmothers is interesting to account for part of the argument I develop in this article: the statement that child circulation between generations makes maternities in Cape Verde. When a child is born, mother and grandmother are mobilized and complement each other in the task of

20 Furthermore, it is important to clarify that, as part of a Creole society - by definition the result of a social dynamic in which strengths, processes, values and symbols from two civilizations (African and European) are mixed, clashing and interweaving, resulting in a third entity (Trajano Filho, 2006) - family organization in Cape Verde reveals practices and models which compete, oscillating between one civilization and the other. Thus, while practices which reproduce a family system such as the one described here take place, so do values built upon a model of nuclear family in which a couple resides together and with their children, according to the European model regarded as ideal particularly by women. We have, on the one hand, practices which reproduce local forms (coherent with what is regarded as an African model) of family organization, and, on the other, existence of a coveted ideal model which, with difficulties, reproduces the nuclear conjugal model. 
raising and educating this child. In a way, for a child to be with a grandmother is complementary to being with the mother, and this is expressed in the complementariness of the words "mother" and mamã. Maternity is, therefore, a processual category and can only be fully exercised in the united efforts of two generations. Being a mother is a process which starts when a child is born and is only fully completed when the woman becomes a grandmother. It takes two women to raise and provide for a child. ${ }^{21}$

Maternity and filiation, in this case, are not dyadic relations, restricted to the mother-child dyad. We are faced with a triangular relation, with a third party as the intermediary - the maternal (or paternal) grandmother - who takes on a fundamental role in both meanings of mother and child. Both roles, although granted by consanguinity and the centrality of the motherchild dyad in this society, do not seem sufficient for construction of feelings of proximity. This feeling requires reassurance, reinforcement and daily experience of living together and constantly caring for the other. The daily maintenance of blood ties takes place in the relational domain of grandmothers and grandchildren, strengthening bonds of affection and proximity between mothers and children. These apparently dyadic relations are actually strengthened and maintained thanks to connection to a third party.

\section{Paternities}

The theoretical line of thought I have used to analyze family organization in Cape Verde resides in the idea of constructing proximity (and, consequently, distance). Having something in common is the basis for proximity - sharing, exchanging goods, services, emotions, reproduction and meaning make up the essence for construction of relations between blood relatives. The family is thus the ideal space for reciprocity and if it is broken, kinship relations are emptied to the extent of becoming mere memories.

As mentioned in previous pages, the relation between parents and children is characterized by distance. The father is a figure which does not share in children's relatedness. I frequently heard my interviewees speak of male absence in the domestic universe, in addition to witnessing it in my daily routine in Boa Vista's backyards. Men were scarce in these spaces. The logical

21 For a more detailed analysis of maternity in Cape Verde, see Lobo, 2010. 
conclusion, therefore, may confirm data which comes up in Cape Verde's family politics: Cape Verdean families are afflicted with paternal absence syndrome. ${ }^{22}$ However, before coming to this conclusion, I would rather talk about the relation between fathers/children (and, consequently, mães-de-filhos/paisde-filho ${ }^{23}$ from a different standpoint, as a relation triangulated by the mother or sister of the father.

My argument is that, in addition to uniting generations at a stage of the domestic cycle which could be characterized by dispersion, children in circulation may counter the male tendency to move away from a new family. This approximation happens through the relation between the child and women from the paternal family, considering that a woman may provide housing for children of a male relative - mothers may take care of children of their children and sisters may take in children of their brothers. Grandmothers and paternal aunts are, therefore, mediators between fathers and children.

I remember the relation between Bia and her grandson, son of her son. The boy was the result of an affectionate relation which had lasted for some time, with relative stability, since the young lady came to sleep with Bia's son in her house, sent her food and participated in domestic production. According to Bia, the young lady's pregnancy was marked by some tension, since rumors spread of the possibility of her son not being the father of the child. On the birthdate, Bia went to the hospital before her son arrived. According to what she told me, only by looking at the baby could she know whether it was his. After confirmation, the son was advised to register the baby and give him his name. Over time, Bia managed to bring the grandson to live with her. The main argument was that she was better off financially to aguentar the boy.

The child's mobility, however, was a constant threat which loomed closer with each fight the couple had. I witnessed some of the child's comings and goings, and Bia's concern and anxiousness with each departure. Many were the accounts of poor treatment at the maternal grandmother's house - the

22 Current government, along with some non-governmental organizations, has prepared documents and held debates to formulate policies to combat the "fragile" nature of Cape Verdean families, which is largely due to paternal absence in the family universe. This absence is formulated in the idea of paternal absence syndrome.

23 These are the commonly adopted names to refer to the person with whom someone had children. Additionally, when the couple has a conjugal relation, this is the label given to the partner, my father-ofchild or mother-of-child. 
boy was poorly fed, wandered the streets dirty, was not put to sleep at the right time, bathed in cold water etc. The dispute between grandmothers was tough and both made use of rumors and pampered the child to lure him. Bia influenced her son to pick up the boy, since, as the father, he had that right. As a consequence, the boy moved between the poles, to a certain extent encouraging relations between the two different domestic units and keeping the couple together. ${ }^{24}$

In a context in which the affectionate relation between mãe-de-filho and pai-de-filho is, at a first moment, marked by instability, the offspring of this relation, by means of circulation, creates a link between families, which may guarantee that the man will return cyclically to that woman, becoming involved in a conjugal relation which may culminate in a marriage (thus the importance of being a mãe-de-filho). Thus, children, in addition to producing filiation bonds, when circulating, start alliances.

Kinship studies have taught us to study relations, rather than individuals. It is in accordance with this idea that I present my argument that affectionate relations between a man and a woman become strengthened both by the birth of a son and the relation between family groups which this child sets in motion on a daily basis. This mobility, therefore, simultaneously confirms and challenges ideas of relatedness and sociability. If birth and confirmation of paternity are founding elements in this relation, sine they come from blood, it is only in daily sharing that a lasting feeling of affection associated with relatives is constructed. We are, therefore, looking at a two-way street, because if a birth as a founding act reaffirms the biological meaning, relations "made" on a daily basis are the ones which set the example for the relatedness universe in the process for formation of this child as a person.

The paternal grandmother is fundamental in this process. She is the third element capable of establishing the connection between father and child in a social context in which relations between them is seen as loose and weak. And, in fact, it is under these conditions that children define their relation with their parents, marked by distance and little affection. However,

24 As exemplified in Bia's family story, even during times when the child does not live with paternal relatives, they approximate affinity bonds by means of mobility between houses. When the little ones start becoming independent, their circulation for transportation of objects and food facilitates this mobility and more luring grandmothers win the company of their grandchildren for more time. The will of the child was the answer I got when I asked, on several occasions, about the house where little ones lived. 
through the mother and other women in the family, he establishes a relation of "distant presence" in the universe of the child. By registering and naming the child, authority and imposed respect, sporadic financial assistance and direct or indirect demonstration of love - actions widely mediated by the mother or sister - men are found, in a presence marked by distance, in the child's relational universe.

Lastly, I point out that the relation of relative distance does not take away from the father the desire to have children. Having a child is an important value in the male universe, like having a female partner (or many). Both are symbols of manhood constantly shown in conversations among men. However, while women like the idea of being close, men, as pais-de-filhos, are involved in the domestic universe by means of distant belonging. ${ }^{25}$ Men are supposed to start a family (which implies having children), but his relationship with her is marked by a relative distance, mediated by relations which are constructed between women and children who circulate between the two families involved.

\section{The value of children}

Many studies in African ethnographic contexts show that people are held in high esteem and, moreover, are considered as social and political "capital" of sorts, with each person adding different advantages to the group. If a person is a fundamental value, rights-in-persons take on a central role in this context, and the status of each person can be considered as the set of rights possessed by this person over other people or objects, in addition to the corresponding duties.

It is important to remember that rights-in-persons are transferable, with compensation. In kinship, these rights can be manipulated to increase the number of persons under the domain of one individual, and the forms under which rights are transferred are of paramount importance in the African context (see Kopytoff \&Miers, 1979; Parkin \&Niamwaya, 1987; Radcliffe-Brown, 1952 for more on this regard).

25 In this case it should also be kept in mind that relations and positions of individuals in the domestic universe are not permanent, but processes constructed throughout their trajectories. Age brings men closer to the mãe-de-filho and, as Boa Vista women say, become calmer, staying at a single domestic unit. It is at this moment that affectionate relations are established in official marriages. 
By bringing this discussion to the topic of Cape Verdean families and highlighting the value of persons in a society characterized by scarcity of resources, exportation of its members and importance of family life, we see children as a fundamental value. Women who have a child know that this child is not only an immediate asset, but a long-term one as well: a baby is at the center of reproduction of relations between relatives and neighbors, encouraging visits, parties and gathering of women from the families of both father and mother. Furthermore, children, starting at the age of 5 or 6 , run errands, keep company and circulate among houses. Lastly, as adults, they help support their elders.

Given the impossibility of aguentar a child alone, created by the system itself, the ideal person for a mother to share the value of her children is her own mother, the child's maternal grandmother. As shown here, to maternal grandmothers, grandchildren are an asset which ensures centrality in the domestic universe. For the mother of the child, leaving the child with the maternal grandmother may be a guarantee that she will always be remembered as a good mother, even in cases of prolonged physical distance. The value of children also extends geographically, and she is a fundamental link between the families of the father and mother, as well as other relatives.

A woman thus shares her children as she shares food, goods and information. In a system with matrifocal tendencies, all female production is for creation and maintenance of relations and child mobility is a component in this practice: it reproduces female centrality and increases the number of women to whom an individual owes loyalty. In turn, children have, in light of their relations with women (from the maternal and paternal families), a safe haven for emotional comfort and transmission of material assets and values.

In a society such as the Cape Verdean one, family groups therefore take on a special character, a porous space which is fruitful for construction of relations of belonging, transmission of goods and values. If this privileged space is marked by the distant character of men as fathers and partners, female centrality seems to be the space for belonging by excellence. Child mobility, made possible by the important role of mobility in this society, results in triangulation relations based on grandmothers. These relations, in the context of this study, are seen as forms of alliance which overcome filiation in the process of formation of relatedness for a child, which provides the elements that are necessary for insertion in the world as a complete person. 


\section{Bibliografia}

CARSTEN, Janet. 1991. "Children in between: fostering and the process of kinship on Pulau Langkawi, Malaysia”. Man, new series, 26(3): 425-443.

CARSTEN, Janet. 2000. "Introduction". In: J. Carsten (ed.), Cultures of relatedness. New approaches to the study of kinship. Edinburgh: Cambridge University Press. pp. 01-36.

CARSTEN, Janet. \& HUGH-JONES, Stephen. (eds.). 1995. About the house: LéviStrauss and beyond. Cambridge: Cambridge University Press.

COUTO, Claudia. 2001. Estratégias familiares de subsistências rurais em Santiago de Cabo Verde. Coleção Teses. Lisboa: Instituto da Cooperação Portuguesa.

DIAS, Juliana. 200o. Entre partidas e regressos: tecendo relações familiares em Cabo Verde. Dissertação de Mestrado apresentada ao PPGAS do Departamento de Antropologia da Universidade de Brasília, Brasília.

FONSECA, Claudia. 2006. Caminhos da adoção. São Paulo: Editora Cortez. FORTES, Meyer. 1969. Web of kinship among the Tallensi: the second part of an analysis of the social structure of a trans-volta tribe. London: Oxford University Press.

FORTES, Meyer. 1974. "O ciclo de desenvolvimento do grupo doméstico". Cadernos de Antropologia, 9: $20 \mathrm{p}$.

GOODY, Esther. 1982. Parenthood and social reproduction: fostering and occupational roles in West Africa. Cambridge: Cambridge University Press. HOWELL, Signe. 2009. "Adoption of the unrelated child: some challenges to the anthropological study of kinship". Annual Review of Anthropology, 38: 149-166.

KOPYTOFF, Igor. \& MIERS, S. 1979. "African slavery as an institution of marginality". In: Kopytoff \& Miers (orgs.), Slavery in Africa: historical and anthropological perspectives. Madison: The University of Winsconsin Press. pp. 03-48.

LÉVI-STRAUSS, Claude. 1976 [1967]. As estruturas elementares do parentesco. Petrópolis/São Paulo: Vozes/EDUSP.

LOBO, Andréa. 2001. Seca, chuva e luta. Reconstruindo a paisagem em Cabo Verde. Master's Degree dissertation for the PPGS in the Departament of Anthropology of the University of Brasilia, Brasilia.

LOBO, Andréa. 2006. Tão longe e tão perto. Organização, familia e emigração feminina na Ilha de Boa Vista - Cabo Verde. Doctor's Degree Thesis for the PPGS in the Departament of Anthropology of the University of Brasilia, 
Brasília.

LOBO, Andréa. 2010. “Um filho para duas mães? Notas sobre a maternidade em Cabo Verde". Revista de Antropologia, 53:117-146.

MAUSS, Marcel. 2003. "Ensaio sobre a dádiva. Forma e razão da troca nas sociedades arcaicas”. In: Sociologia e antropologia. São Paulo: Cosac \& Naify. pp. 183-314.

MODELL, Judith. 1999. "Rights to the children: Foster care and social reproduction in Hawa'i”. In: S. Franklin; H. Rageré (eds.), Reproducing reproduction. Kinship, tower and technological innovation. Philadelphia: University of Pennsylvania Press. pp. 153-172.

MONTEIro, Antonio. 1997. Comunidade imigrada. O caso da Itália. Visão sociológica. São Vicente: Gráfica do Mindelo.

PARKIN, David. \& NYAMWAYA, David. (eds.) 1987. Transformations of african marriage. Manchester: Manchester University Press.

PINA CABRAL, João de. 2010. "Xará: namesakes in Southern Mozambique and Bahia (Brazil)". Ethnos, 75(3): 323-345.

RADCLIFFE-BROWN, Alfred Reginald. 1952 "Introduction”. In: A. R.

Radcliffe-Brown; D. Forde (eds.), African systems of kinship and marriage. London: Oxford University Press.

SCHNEIDER, D. 1984. A critique of the study of kinship. Ann Arbor: University of Michigan Press.

TRAJANO FILHO, Wilson. 2006. "Some problems with the Creole Project for the nation: the case of Guinea-Bissau". Paper presented at the Seminar Powerfull Presence of the Past, at the Max Planck Institute, Halle, Germany.

VIEGAS, Suzanna. 2003. "Eating with your favorite mother: time and sociality in brazilian amerindian community". The Journal of the Royal Anthropological Institute, 9(1): 21-37.

WHITE, Suzan, WENZEL, Geissler \& ALBER, Erdmute. 2004. "Lifetimes interwined: african grandparents and grandchildren”. Africa, 74(1): 01-06. 


\section{About the author}

Andréa Lobo is an Anthropologist from the University of Brasilia's

Department of Anthropology. She is a specialist in African Anthropology,

especially the Creole society in Cape Verde, where she has carried out her ethnographic research in the past years. Her research interests include topics such as kinship and transnational flows - women migration, child mobility, commodities flows.

Contact: andreaslobo@yahoo.com.br. 